\title{
電子計算機による腐食試験データの処理*
}

\author{
小幡孝一郎** 吉岡 和夫**
}

\section{Computer Applications in Corrosion Data Retrieval}

\author{
Kôichiro Obata and Kazuo Yoshioka
}

A filing system for corrosion data retrieval has been studied. This system of computer programs accepts as input the original data obtained at laboratories or plants and generates as output the data file by which retrieval for desired corrosion data becomes easier and faster. This system can also generate as output the corrosion charts to show the influence of environmental conditions e. g. the concentration of corrosives and the temperature on materials. These charts are useful to know not only the range of the corrosion resistance of materials but also the influence of environmental factors.

\section{1. 緒言}

実験室および実装置における腐食試験結果が多数集積 するに従って，乙れらの結果を十分に活用するために は, その整理が重要な問題となってきている。腐食試験 データの処理方法としてはパンチカードシステムによる 方法や，ピーカブーシステムによる方法などがある1)。 パンチカードシステムは単純で, 情報の抄録など種々の 事項を記入でき，原情報に到達することが割合容易であ る。しかし, 索引語の数に限度があり, またカードの数 が多くなるにしたがって検索が困難になってくる。ピー カブーシステムは索引用語の増減をカード枚数の増減に よって自由に行なうことができ, 検索も容易であるが, 原情報やその抄録を直接見ることができない。そこでこ れらの欠点を補い, さらに必要な腐食試験データを迅速 に得るとともに, そのデータを処理する方法を検討し た。すなわち試験材料に対して, 腐食液の組成・液温な ど試験環境, 試験方法, 侵食度・腐食形態など試験結果 および簡単な備考など関連事項をファイルしておき，試 験材料および関連事項が質問者の要求を満足する時それ らを結果として示し，さらに侵食度と腐食液の組成・濃 度および温度との関係を図示するととなどデータの整理 作図機能を持たせることを目的として検討を行なった。 これにより，耐食材料の選定にあたって，腐食環境に対 する耐食性の把握が容易となり，またての方法は腐食に 対する各種因子の影響を検討する上で有効である。

\section{2. システムの構成と機能}

\section{$2 \cdot 1$ 概 要}

* 昭和43年10月17日第15回腐食防食討論会（北九州市）に括いて発表

** 味の素 (株) 中央研究所 (川崎市鉿木町 2964)
電子計算機による情報検索システムはおもに文献情報 を対象とした分野で数多く作られている。材料選定のた めにてれらのシステムをそのまま利用することはむちろ ん可能であるが, 次のような特殊性を考慮するとき，こ のことは必ずしも有効ではない。すなわち,

(1) データの構造

文献情報の場合には文章そのもの（たとえば標題）が 情報となるので, 語単位の検索が問題になるが, 材料に ついての腐食試験情報の場合は, 実験の条件や結果が重 要なので, 各項目に統一性を持たせてファイルしておけ ば内容の検索ははるかに容易である。

(2) 使用目的

文献情報検索では，不特定多数を相手とした情報提供 が主な目的であるのに対して，材料選定の場合は，特定 個人の特定質問に答えることが主目的となる。

てのような特性に着目して材料選定のためのプログラ ムを作った。したがっててのプログラムは一般の実験デ 一タの保存検索用としても使用可能である。

\section{2 構 成 \\ $2 \cdot 2 \cdot 1$ ファイルの構成}

このシステムは複数個のファイルの処理が可能であ る。各ファイルはファイル名およびデータ群から構成さ れている。各データは一つの実験に対応し，いくつかの 項目からなっている。腐食試験データにおいては, 金属 亡非金属とでデータの項目が若干異なるのでファイルを 分ける。金属材料の場合, ファイルは 20 の項目亡, 備考 とからなっている。すなわち，第一項から順に材料名， プロジェクト名, 腐食液名, 第一成分名, 第一成分濃 度, 第二成分名, 第二成分濃度, 第三成分名, 第三成分 
表 1 腐食試験データファイル

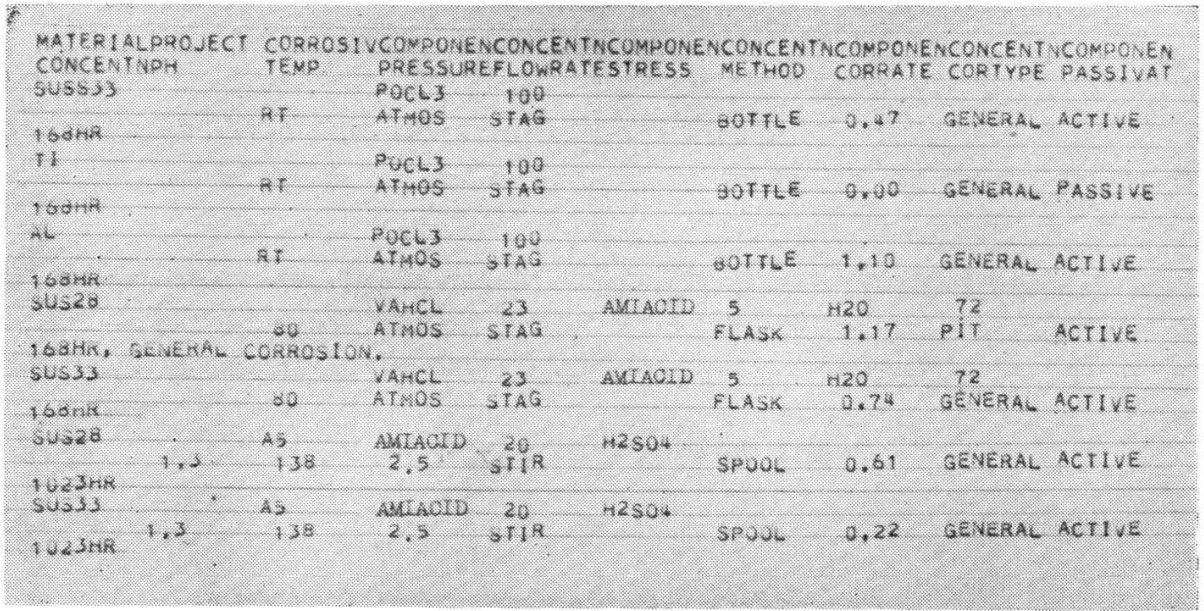

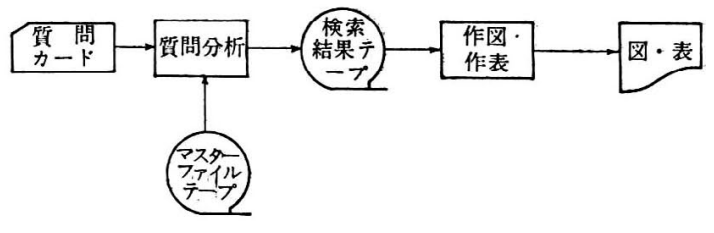

図 1 システムフローチャート
濃度, 第四成分名, 第四成分濃度, 腐食液の $\mathrm{pH}$, 試験 温度, 試験圧力, 流動状態, 付加応力, 試験方法, 侵食 度, 腐食形態, 不働態化の有無の 20 項目と備考之から なっている。ここで該当する項目に記述がない時は空欄 のままにしておく。また備考の欄は何を書いても良い が，この欄で検索することはできない。

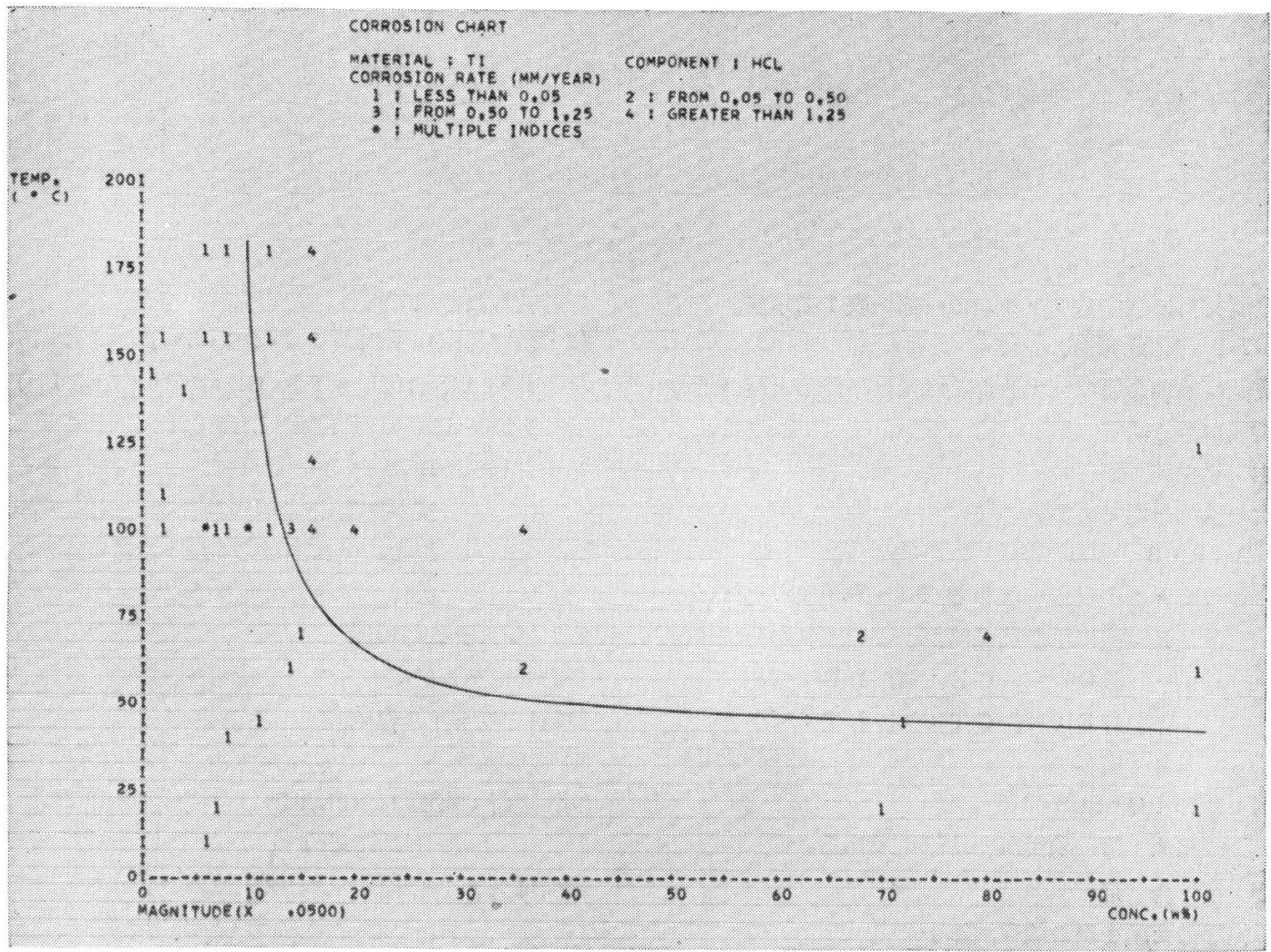

図 2 チタンの腐食に及ぼす塩酸の濃度と温度の影響 
表 2 質問例

表 3 検索結果のファイル

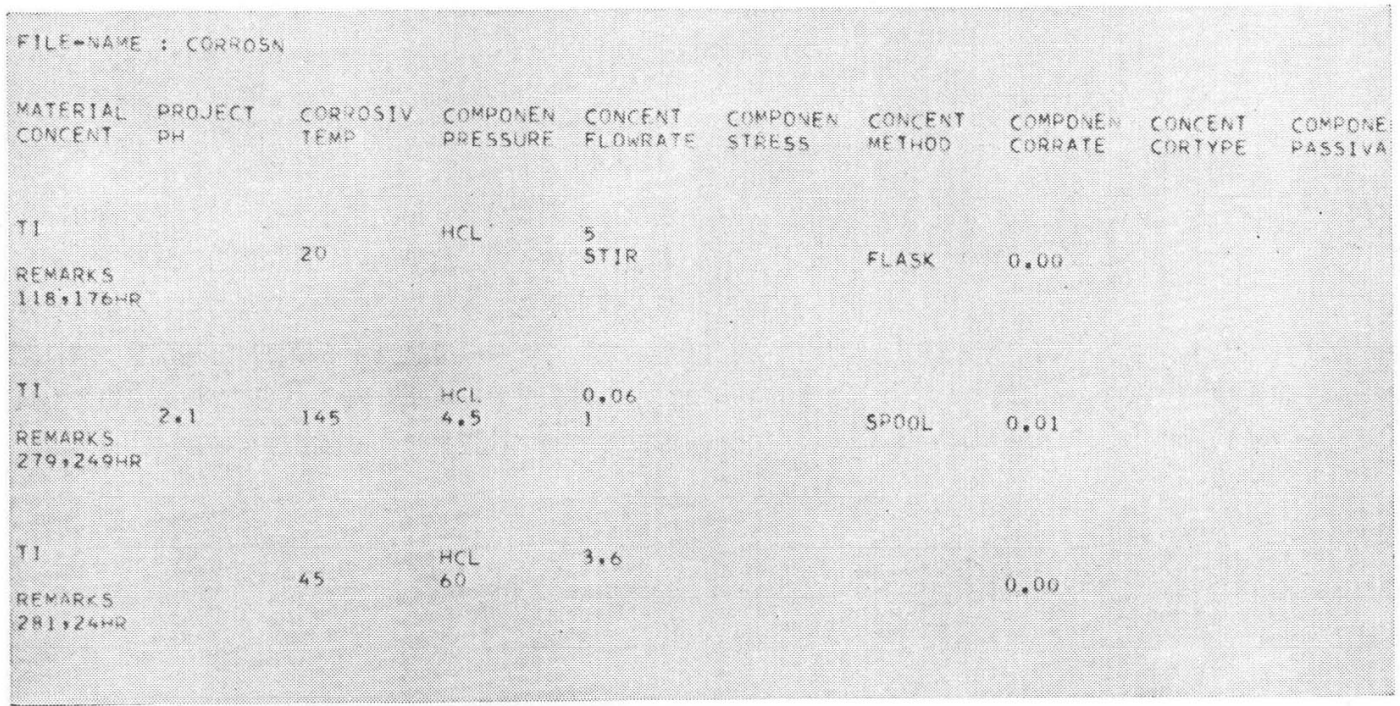

金属材料に関するファイルの一部を表 1 に示す。

$2 \cdot 2 \cdot 2$ 問 形 式

質問は論理命題で与える。とれには単純形と複合形の

2 種類がある。

(1) 単 純 形

次の論理命題である。

$\mathbf{A} \cdot \mathbf{R} \cdot \mathbf{B}$

ととで A : 項目名すなわち T 1〜T 20 のいずれか

$\mathrm{R}$ : 次に示す関係演算子のいずれか一つ

$$
\begin{aligned}
& \mathrm{EQ}:=, \mathrm{GE}: \geqq, \mathrm{L} \mathrm{E}: \leqq, \\
& \mathrm{NE}: \neq, \mathrm{GT}:>, \mathrm{L} \mathrm{T}:<
\end{aligned}
$$

$\mathrm{B}:$ 内容

例 : T $1 \cdot \mathrm{EQ} \cdot \mathrm{SUS} 33$

意味 : 第一項目が SUS 33 である。

(2) 複 合 形

単純形の命題を次の論理演算子

*: AND, + : OR, - : NOT
で結合したあのである。

例 : ( $\mathrm{T} 3 \cdot \mathrm{EQ} \cdot \mathrm{HCL} * \mathrm{~T} 4 \cdot \mathrm{GE} \cdot 5 * \mathrm{~T} 4 \cdot \mathrm{LE} \cdot 1 \phi+$ $\mathrm{T} 5 \cdot \mathrm{EQ} \cdot \mathrm{HCL} * \mathrm{~T} 6 \cdot \mathrm{GE} 5 * \mathrm{~T} 6 \cdot \mathrm{LE} \cdot 1 \phi) *$ $\mathrm{T} 13 \cdot \mathrm{GE} \cdot 5 \phi * \mathrm{~T} 18 \cdot \mathrm{LE} \cdot \phi .1$

意味 : HCL が第一または第二成分で, その濃 度が $5 \%$ 以上 $10 \%$ 以下で，温度が $50^{\circ} \mathrm{C}$ 以上，侵食度が 0.1 以下であることの 4 条件をすべて満足すること。

\section{$2 \cdot 3$ システムの機能}

このシステムは次の三つの機能を有している。

\section{2・3・1 ファイル作成}

(1) 新規作成

(2) 更新 : 修正 (REPLACE), 削除 (DELETE), 追 加 (INSERT)

更新はファイル単位, データ単位のいずれす可能であ る。

2.3.2 問処理機能 
(1) 質問分析

INPUT された質問を計算機 が実行できる形式に変換 する(質問表の作成)。

(2) 検索

指定されたファイルからデータを取り出し, 質問表に 従って条件を満足しているか否かを調べる。満足してい ればそのデータを LINE PRINTER に打ち出す。

\subsection{3 データ整理・作図機能}

図 1 にこの機能のシステムフローチャートを示す。

図 2 はこの機能を用いてチタンの塩酸に対する腐食試 験の結果を整理し, 塩酸の濃度と温度に対してその侵食 度を図示したものである。表 2 はこの場合の質問例で,

表 3 は LINE PRINTERに打ち出された結果のファイル の一部である。この図はチタンの塩酸による侵食度を液 温および濃度に対して図示したもので，侵食度は，0.05 $\mathrm{mm} / \mathrm{yr}$ 以下を $1,0.05 \sim 0.125 \mathrm{~mm} / \mathrm{yr}$ を $2,0.125 \sim$ $0.50 \mathrm{~mm} / \mathrm{yr}$ を $3,0.50 \mathrm{~mm} / \mathrm{yr}$ 以上を 4 としてある。 この関係を図示するととによって耐食性の範囲の把握が
容易となり，また他の因子の耐食性に及ぼす影響を検討 することが容易となった。たとえば，図 2 によれば，チ タンは塩酸に対して図示した曲線より下の部分で耐食性 が認められ，また曲線より上の領域でかなりはなれて "1" の点があるのは他の成分の影響であることが予想さ れる。

3. 結

本報告は電子計算機を利用して腐食試験データをファ イリングし，そのファイルを用いて腐食試験データの検 索を容易に，迅速に行なうことを検討し，さらにそのデ 一タを整理して図示することを検討したあのである。こ の手法は耐食材料の選定にあたり，各種材料の耐食性の 範囲の把握を容易にし，またその耐食性に及ぼす種々の 因子の影響を検討する上で有用である。

（昭和 44 年 2 月 10 日受理）

\section{引用 文 献}

1) G. B. Elder: Mater. Prot., 6, No. 3, 47 52 (1967)

\section{新刊紹介}

\section{革食科学と防食技術}

伊藤伍郎：511頁 (1969) コロナ社（ $¥ 2,000 ）$

コロナ社の標準金属工学講座の 1 巻として本年 2 月出 版された。

腐食の様式, 電気化学, 嗆食速度, 接触腐食, 環境因 子, 冶金的因子, 不働態, 孔食, 応力と進む前半(13章) は腐食科学に対応する部分といえようが, 著者が執筆に 当って念じた, 工学者一般にとってとっうきにくい腐食 現象を，専門としない人々にあ抵抗なく読み進んであら えるようという意図は立派に果たされている。

14章に金属材料の腐食特性各論 ( $\mathrm{Fe}, \mathrm{Cu}, \mathrm{Ni}, \mathrm{Al}, \mathrm{Mg}$, $\mathrm{Ti}, \mathrm{Zr}, \mathrm{Ta} \cdot \mathrm{Nb}$ ) を置いて, 以下自然環境, 各種工業に おける問題, ガス腐食, 防食, 試験, 参考書にいたる全 20章の後半は防食技術に力点がおかれている。
Uhlig の著書よりあ新しく詳細であり，したがって入 門の教科書としてのみでなく，本誌の読者が座右におい， て参考にするにあ適している。

てのように腐食の全域を一人で執筆するというのにて の著者はむっとあ適した地位にあるわけであるが，日で ろの幅広い仕事の領域に裏打ちされた，すぐれた本書の 出現を喜ぶものである。

近年における腐食防食分野の著書の多きはまことに同 慶のいたりであるが，本邦でもとのような総合的教科 書・参考書が一人の著書の手になって，よくまとめられ た形で現われるとなると，本委員会で現在企画が進行中 の便覧のようなものは，可能な限りデータ・ブックであ りたいと願うものである。

(Y. H.) 